\title{
WHAT IS BEHIND A STUDENT'S CHOICE FOR BECOMING A DOCTOR?
}

Luiz Roberto Millan, Raymundo Soares Azevedo, Eneiza Rossi, Orlando Lúcio Neves De Marco, Marília Pereira Bueno Millan, and Paulo Correa Vaz de Arruda

MILLAN LR et al. What is behind a student's choice for becoming a doctor? CLINICS 60(2):143-150, 2005.

PURPOSE: To determine the reasons for choosing the medical profession by interviewing freshmen medical students from the Faculty of Medicine, University of São Paulo and investigating their socio-economic and psychological profiles, as well as to determine whether there are gender differences.

METHOD: One hundred and sixty three freshmen medical students answered a questionnaire regarding their socioeconomical profile. Of those, 30 female and 30 male students underwent a face-to-face interview regarding the career choice, the Thematic Apperception Test (TAT) and the 16 Personality Factor Questionnaire (16 PF). The results were analyzed qualitatively and by Mann-Whitney, $\chi^{2}$, Fisher's Exact, and $r_{p}$ coefficient tests.

RESULTS: Most students were middle class, catholic, and had physicians in their families. Students of both genders had made an: early choice of the medical career and a persistence in taking exams many times, even after being discouraged. They also showed an awareness of the difficulties and limitations in developing their careers. The study revealed a strong valuation of the humanistic aspects of medicine; openness to new experiences; a deep personal identification with the choice of profession; a critical need for fulfillment in their careers; and conscious and unconscious desires to help people and be recognized for their usefulness, without being narcissistic. Female students were more sensitive $(P<.001)$ and less imaginative $(P=.005)$ than male students, who were more utilitarian and less grounded; female students tended to present greater emotional maturity while male students presented a greater tendency towards competition, and were more ambitious.

CONCLUSIONS: Students of both genders have similar socio-economical profiles and features regarding their motivations for choosing the medical profession. Slight differences were found regarding some psychological aspects.

KEYWORDS: Medical students. Personality. Career choice. Gender. Education.

The question of the ideal personal characteristics for entering the medical profession is an age-old concern. Hippocrates discussed this subject in his texts, calling the attention to the characteristics necessary to become a doctor. The Father of Medicine proposed that doctors should have natural skills, culture, disposition for studying, a strong background, perseverance, enjoy work, and time availability. However, worldwide, the selection of new medical students usually does not take into consideration those characteristics, but rather emphasizes cognitive aspects.

From Grapal - Psychological Couseling Group, Faculty of Medicine, University of São Paulo; Department of Pathology, Hospital das Clínicas, Faculty of Medicine, University of São Paulo, and Psychology Institute, University of São Paulo - São Paulo/SP, Brazil.

E-mail: luizmillan@uol.com.br

Received for publication on August 18, 2004.

Accepted for publication on January 06, 2005.
Many factors have been cited as determinants for choosing the medical career: personality; conscious factors such as the desire for helping people, preference for biological knowledge, and scientific curiosity; unconscious factors such as the capacity for reparation and sublimation; socioeconomical factors including family influence, amongst others. ${ }^{1-5}$ However, most studies on this matter have only made a partial approach given the methodological difficulties in obtaining a complete picture of students' motivations.

The vocational issue was studied in the $15^{\text {th }}$ and $16^{\text {th }}$ centuries, but it was only by the end of the $19^{\text {th }}$ century that vocational counseling became a scientific discipline, thanks to the works of Galton (1883), Cattell (1890), and Binet (1895) who created the first technical instruments and the conceptual basis for this area. 
During the last 100 years, vocational theories have been divided into 4 groups: (i) psychological theories represented by Parsons (1909), Ginzberg (1951), Gellat (1962), Holland (1966), and finally the psychodynamic theories developed by Freud (1905) and the psychoanalysis school after him; (ii) sociological theories represented by Miller \& Form (1951), Caplow (1954), and Bordieu (1972), among others; (iii) economical theories developed by Clark (1931) and Smith (1949); (iv) general theories defended by Blau (1968) and Bohoslavsky (1971). ${ }^{6-7}$

Historically, women were considered unable to be doctors, among other professions, on the argument that their personality profile was not suitable. By the end of the $19^{\text {th }}$ century, women were gradually accepted into the medical profession, and became more and more present in this area. However, and in addition to the fact that women became socially accepted in the medical profession, would there be any other reason for the increasing number of women in the profession? Do they choose medicine for the same reasons as men do? Do they have the same vocation?

Does it make sense for any individual to work hard, lose leisure and family time, keep studying after graduation to stay updated, and to live in contact with suffering and death of people in hospitals and clinics for a long period of one's life? In spite of such negative factors, applicants continue to present themselves, inlarge numbers, year after year to the medical schools in most countries. One may think of this as contra intuitive or insanity. But it happens. Why?

It is thus important to jointly study the many aspects of vocation to better understand the medical students in our institutions. In-depth knowledge about students and their motivations to become doctors provides fundamental support for improved pedagogical action, thereby preventing psychological problems, and optimizing education during the undergraduate period.

The purpose of this study was to determine the reasons for choosing the medical profession by students in a group of freshmen at the Faculty of Medicine, University of São Paulo by investigating their socio-economical and psychological profiles, and to determine whether there are genders differences.

\section{METHOD}

Subjects - This study was carried out among freshmen of the Faculty of Medicine, University of São Paulo, one of the largest and the highest ranking of Brazilian universities, from March to July 2000.

Instruments - In this study, 4 instruments were used. The first was a self-answered socio-economical questionnaire that included personal details on gender, age, race, birth place, religion, marital status, parents' degrees and professions, existence of doctors in their families, number of attempts to enter medical school (ie the number of repeat submission to the difficult admission exam, which is called the vestibular in Brazil), information about fundamental- and high-school courses, and family income.

The second instrument was a face-to-face interview regarding the career choice, developed to evaluate the following aspects: the moment when the career choice was made; interest in searching for information about the medical profession before the vestibular exam; alternative career options considered before trying for the medical career; identification with any doctor; counseling against being a doctor; consideration of a medical specialty in the beginning of the course; opinions about the present-day medical profession; expectations about the difficulties during undergraduate medical studies; expectations for his/her future; the influence of the profession on his/her private life; option to marry a doctor; construction of a list of necessary characteristics a doctor must have; auto-evaluation on those characteristics; a list of what cannot be taught to a doctor; ideas on how to become a successful doctor, and finally the conscious motivation to become a doctor.

The third instrument used was the Thematic Apperception Test (TAT), developed by Murray. ${ }^{9}$ This is a method used to reveal unconscious impulses, emotions, feelings, conflicts, and complexes that make up the personality. The most important feature of this test consists of its capacity to show unconscious trends, many times not acknowledged by the individual.

The fourth instrument, the 16 Personality Factor Questionnaire (16 PF) $5^{\text {th }}$ edition, was developed by Cattell to evaluate personality traits and profiles of adolescent and adult populations. The standard 16 PF paper-and-pencil form was completed by each student, evaluating the following bipolar dimensions of personality: A - Warmth (Reserved vs. Warm); C - Emotional Stability (Reactive vs. Emotionally Stable); E - Dominance (Deferential vs. Dominant); F - Liveliness (Serious vs. Lively); G - Rule-Consciousness (Expedient vs. Rule-Conscious); H - Social Boldness (Shy vs. Socially Bold); I - Sensitivity (Utilitarian vs. Sensitive), L - Vigilance (Trusting vs. Vigilant); M Abstractedness (Grounded vs. Abstracted); N - Privateness (Forthright vs. Private); O - Apprehension (Self-Assured vs. Apprehensive); Q1 - Openness to Change (Traditional vs. Open to Change); Q2 - Self-Reliance (Group-Oriented vs. Self-Reliant); Q3 - Perfectionism (Tolerates Disorder vs. Perfectionist); Q4 - Tension (Relaxed vs. Tense). Factor B, Reasoning (last questions on the form), was excluded because these students entered the medical course through a selective process that considers the cognitive performance. 
The global factors are the result of the combination of the bipolar factors, namely: Factor I, Extroversion, the combination of factors A, F, H, N, Q2; Factor II, Anxiety, the combination of factors $\mathrm{C}, \mathrm{O}, \mathrm{Q} 4$; Factor III, ToughMindedness, the combination of factors A, I, M, Q1; Factor IV, Independence, the combination of factors E, H, C, Q1; and Factor V, Self-Control, the combination of factors F, G, M, Q3.

\section{Procedures}

During the first week of the school year, a questionnaire was answered by 163 (103 male and 60 female students) of the 175 freshmen (113 male and 62 female students), regarding the socio-economical profile. From those, considering the age proportion of the group, 30 female students were randomly selected and their profile was analyzed as to race, religion, marital status, family income, nationality and birthplace. In the sequence, 30 male students were selected to pair these variables with the female group. All 60 students were invited to participate in the study, and after the objectives and instruments were presented, the students signed a written informed consent form. The face-to-face interview was conducted with 4 students a day by a psychiatrist. On the same day, two psychologists conducted the TAT test. Five standard pictures (number 1, 2, 3RH, 8RM, 20) were showed to the students and they were asked to tell a story about each picture. After that, students completed the $16 \mathrm{PF}$.

In order to verify certain differences in respect to gender, each aspect of the questionnaire and the interview was categorized by the author into groups of answers and analyzed using the $\chi^{2}$ test or Fisher Exact test. The level of significance was fixed at $5 \%$. A senior psychologist evaluated the notes and made a psychoanalytical interpretation of the TAT. In order to verify differences with respect to gender, each 16 PF bipolar dimension of personality (raw and standardized to a score of ten - "sten") and Global Factors were analyzed using the Mann-Whitney test. Scores for each factor were determined automatically by the $16 \mathrm{PF}$ software (Programa de Correção do Teste 16 PF, version 2.2, Centro Editor de Psicologia Aplicada - CEPA, Rio de Janeiro, Brazil). The students' answers were checked using the validity scales proposed by the $16 \mathrm{PF}$ for the following factors: IM - Impression Management; INF - Infrequency; ACQ - Acquiescence. Each individual was classified according to his/her personality factor sten obtained as compared with the proposed sten class for the reference population, namely: $<4$ (lower), 4 to 7 (median), $>7$ (upper). Finally, the analysis proposed by the 16 PF Manual was applied, the mean sten value for each gender group was calculated, and the $r_{p}$ coefficient was determined.

\section{RESULTS}

\section{Socio-economical profile}

The average age of the 60 students enrolled in the study was 18.5 years (ranging from 17 to 21 years), all Brazilian and single, most of them Caucasian, born in the city of São Paulo, catholic, and having parents who received higher education. About $63.33 \%$ of these freshmen had physicians in their family, $25 \%$ of them having fathers who were doctors, and $8.33 \%$ having mothers who were doctors.

Among those students, 44 of them had taken the entrance exam 2 or more times to enter the Faculty of Medicine. Most of them had completed fundamental and high school in private institutions (nongovernmental), as well as the preparatory course before the entrance (vestibular) exam, also a course requiring private payment. In fact, only 1 freshman studied through all grades in (free) government schools. Only 3 students had tried another career before medicine.The main family income was from the father's job (45 students); only 2 students had worked during the high school course, but 10 freshmen intended to have occasional jobs before graduation. The family income profile was typical of Brazilian middle class.

No statistical difference between male and female students was observed in the socio-economical variables that were not paired.

\section{Interview Analysis}

The first item was to check when each student had decided to become a physician. About $40 \%$ of all 60 students related that they had made their decision before entering high school, i.e. before 15 years of age. Most of them had chosen the option during high school (51.7\%). A few students $(8.3 \%)$ made up their minds after that time when preparing for the vestibular exam during an optional and privately financed course. There was no significant difference between genders $(P=.155)$.

Most students had investigated the possibility of a medical career before entering medical school $(93.3 \%$ of them, no gender difference, $P=0.999$ with the most common sources as follows: doctor acquaintances (47); visits to medical schools (15); conferences about the career (14); newspapers, magazines, radio, and television (9); books and manuals (4); spending days with doctors during their activities (3); vocational counseling (3); talking with medical students (1); Internet (1). One third of students (no gender differences, $P=0.999$ ) had considered another career.

Regarding models of identification when choosing a medical career, a greater number of male freshmen had iden- 
tified themselves with someone else, such as relatives, family doctors, friends, and the movie character Patch Adams $(P=.02)$.

On the other hand, students were frequently told not to follow medicine as a profession (around 30\% for both male and female students). Among the arguments used by relatives or friends were the following: life sacrifice, tough course of study, lack of time for family and private life, too much stress in the profession, too difficult to enter the University, emotional immaturity, requirement to live away from the family in the countryside, not having the doctor profile, and disappointment with the course.

When questioned about what they thought about the medical professional, only $10 \%$ of the students had a favorable image of the career, while $35 \%$ believed that favorable aspects go together with disadvantages. For most students $(55 \%)$ there were only unfavorable aspects about the present-day medical career, but their expectations for their future as doctors were optimistic. No statistical difference was found between genders on these issues.

Regarding the difficulties expected during the medical course, the lack of time was the first one reported by both genders, since the course of study is too time consuming. Secondly, the relationship with patients was thought of as an expected difficulty. Thirdly, the excess of subjects to be studied was cited as a problem to be dealt with, followed by difficulties of learning the subjects offered, as well as the stress during the course, the selection for the residency program, the lack of didactic skill of faculty members, and the choice of specialty, among others. No significant difference was found between genders. The majority of freshmen (around 77\%), no difference in gender, reported that they had considered a medical specialty before entering the medical school. Clinical areas were cited by 39 students, followed by surgical specialties (25), and mixed areas (25).

Most students believed that their medical routine would interfere with their private lives, and there was no gender difference in this subject. The arguments cited were lack of time (59), lack of relationship with patients (11), social isolation (8), unpredictable time schedule (7), comprehension of the world different from that of laypeople (4), adequate social conduct (2), delayed parenthood (2), and tiredness due to daily activities (1).

Only 4 male freshmen answered that they would not like to marry a doctor. Reasons given as justification included "the profile of my colleagues does not match mine"; "I am competitive, ambitious, and an individualist"; "I want other subjects to talk about beyond medicine"; "both parents would be absent most of time, and children would be left without parental care"; "I want to know other worlds". The majority $(71.7 \%)$ said they were indifferent regarding mar- rying a doctor, while $21.7 \%$ answered that they would like to marry a doctor, pointing to the following reasons: "Mutual comprehension", "More subjects to talk about", "Similar cultural level", and "Being more companionable".

During the interview, students were asked to list 5 attributes necessary for being a good doctor. Around 92\% listed characteristics of personality they thought were indispensable, followed by professional skill (80\%), good relationship with patients $(60 \%)$, liking the profession $(30 \%)$, and being happy (2\%). The personality characteristics listed most frequently were altruism (54 answers), having a humanitarian attitude (12 answers), being dedicated (9 answers), being responsible ( 8 answers), having humility ( 7 answers), having patience ( 5 answers), being open to new knowledge (4), liking human beings (4), having sensitivity (4), not having prejudice (3), being ethical (3), and being secure (3). No gender difference was detected.

The "good relationship with patients" response was constructed through the interpretation of the many ways students used to express this attribute, namely: being attentive, transmitting confidence, respecting the patient, knowing how to listen the patient, knowing how to make the patient adhere to treatment, treating the patient as a person and not just as a disease, not getting too much involved with the patient, empathy with the patient, seeing the patient as a whole person, following the patient until the end, among others. When students were asked if they had those attributes, all of them answered affirmatively.

The next step was to obtain from the students their opinion on which of those attributes were not possible to be taught during the medical course. The first one pointed out by 44 students was the personality characteristics, followed by liking the profession (16), professional skill (14) and a good doctor-patient relationship (10). No significant statistical difference was observed between genders.

Another point of the interview was about what freshmen regarded as a successful doctor. Again the professional skill emerged as dominant, and this time as the most frequent answer (41 answers), followed by personality characteristics (34 answers), both without gender difference $(P$ $=.165$ and $P=.118$, respectively). On the other hand, liking the profession was cited more by female students (14) than by male students (4), as well as a good doctor-patient relationship ( $P=.005$ and $P=.045$, respectively). Male students (10) pointed out that economical fulfillment was a measure of success in the career, while this was apparently less important for female students (3), the difference being statistically significant $(P=.028)$. Both groups cited some aspects_-personal success, social and personal stability, and the participation in teaching and research-less frequently (less than 5 answers). 
When questioned why they had chosen a medical career, most of them answered that their motivation was based on altruism (40), followed by their intellectual curiosity (23), interest in human relationships (15), influence from someone else (9), professional profile (8), and finally the economical gain (1). No gender differences were found.

\section{TAT analysis}

Students were very cooperative with the psychologists who conducted the sessions, and 2 female and 2 male freshmen declared being enthusiastic about collaborating with this study.

Regarding the formal aspects of TAT, female students reacted more intensely to the presentation of pictures, with expressions such as "My God!", "Wow!", or "What can I say about this one?". Most students, male and female, underwent the test without difficulties. However, 10 of them considered it a hard test, and exhibited unsatisfaction with their performance in telling a story about each picture. It was necessary to stimulate 3 of them to start or to finish telling the story with questions posed by the psychologist, and 2 male students refused to create a story on one picture. One male student became anxious during the test, and 2 male and 1 female students reacted with cynicism.

After gathering all tests (300 stories), it was possible to establish some common outputs for both genders and to detect some differences, in accordance with the psychoanalytical theories initially proposed by Sigmund Freud and developed by Melanie Klein. Most students of both genders showed a trend to remain in a depressive position, which demonstrates that they are emotionally mature. It is important to differentiate the clinical depression (a psychiatric di- agnosis) from this depressive position (a psychodynamic concept developed by Melanie Klein to characterize maturity). Most of the developed stories were the ones expected by the test, revealing that these students are grounded in reality. The career choice appeared to be an important aspect of their identities, with the unconscious function being that medicine was considered by them to be a propitious profession for exerting their capacities for reparation and sublimation (psychodynamic concepts developed by Melanie Klein and Sigmund Freud, respectively), indicating they would be able to take care of other people. It is noteworthy that few students showed unconscious desires to satisfy a narcissism through the success and admiration they might excite as doctors. These stories also revealed that students worked towards fulfilling their ideal with great perseverance and they had well-structured superegos.

Few differences were observed between genders. Female students tended to present greater emotional maturity, a bold sense of responsibility, a better insight on emotional life, a greater need for their parents approval, a greater need to be loved, and to have experienced more intensely the conflicts from their emotional life.

Male students had a strong determination to differentiate themselves from their fathers and in this way establish their own phallic power. They presented a greater tendency towards competition and they were more ambitious. However, they were more insecure about their capacity to develop their own projects.

\section{Personality Factor analysis}

The summary of all personality factors obtained for male and female groups is shown in Table 1.

Table 1 - Sum of ranks for raw and sten scores of personality factors obtained for male and female groups and $P$ values from the Mann-Whitney test.

\begin{tabular}{|c|c|c|c|c|c|c|}
\hline Bipolar dimensions & \multicolumn{3}{|c|}{ Rank Sum for Raw Scores } & \multicolumn{3}{|c|}{ Rank Sum forStens } \\
\hline A - Warmth & 946 & 884 & .645 & 947 & 883 & .630 \\
\hline C - Emotional Stability & 897 & 933 & .789 & 896.5 & 933.5 & .782 \\
\hline $\mathbf{E}$ - Dominance & 833.5 & 996.5 & .226 & 850 & 980 & .328 \\
\hline F - Liveliness & 924 & 906 & .894 & 931 & 899 & .810 \\
\hline G - Rule Consciousness & 1013.5 & 816.5 & .143 & 999 & 831 & .205 \\
\hline H - Social Boldness & 861 & 969 & .424 & 848 & 982 & .316 \\
\hline I - Sensitivity & 1235.5 & 594.5 & $<.001 *$ & 1212.5 & 617.5 & $<.001 *$ \\
\hline L - Vigilance & 855 & 975 & .371 & 850.5 & 979.5 & .331 \\
\hline $\mathbf{M}$ - Abstractedness & 722.5 & 1107.5 & $.004 *$ & 730 & 1100 & $.005 *$ \\
\hline $\mathbf{N}$ - Privateness & 865 & 965 & .459 & 858.5 & 971.5 & .396 \\
\hline $\mathbf{O}$ - Apprehension & 934.5 & 895.5 & .772 & 932.5 & 897.5 & .794 \\
\hline Q1 - Openness to Change & 854 & 976 & .365 & 857 & 973 & .384 \\
\hline Q2 - Self Reliance & 756.5 & 1073.5 & $.018 *$ & 790 & 1040 & .056 \\
\hline Q3 - Perfectionism & 972 & 858 & .397 & 980 & 850 & .329 \\
\hline Q4 - Tension & 887.5 & 942.5 & .683 & 868.5 & 961.5 & .481 \\
\hline
\end{tabular}

* Statistically significant difference 
It can be noted that 2 factors presented significant differences between gender groups, either for raw or sten scores. From these findings, it is possible to say that there is a tendency of the female medical students to be more sensitive (I - Sensitivity) and less imaginative (M Abstractedness) than male students, who are more utilitarian and less grounded. No gender difference was found for global factors, and all answers were considered valid for both groups, although the group of male students presented a higher acquiescence score $(P=0.023)$.

Table 2 shows the number of students classified into each sten class for every personality factor, grouped by gender. It is worth noting that factor I (Sensitivity) points out a significant difference between gender groups, indicating that there were more male students in the lower sten class (more rigid) than female students. Another significant difference appeared related to factor L, where there were more female students in the lower sten class (more trusting) than male students.

The mean sten for each gender group and bipolar personality factor is presented in a graphical form in Figure 1. It can be noted that male students had a high mean sten in factors Q1 (Open to Change) and a low mean sten in factor Q3 (Tolerates Disorder). Although the mean sten of some factors were distinct between genders, like factors $\mathrm{G}$ (RuleConsciousness), I (Sensitivity) and M (Abstractedness), the general profile for both groups were similar, and there was no significant difference according to the coefficient of profile similarity, as proposed by Cattell $\left(\mathbf{r}_{\mathbf{p}}=0.85\right)$.

\section{DISCUSSION}

There is a growing interest in studying medical vocation focusing on gender differences. This is due to the relative recent increase of women entering medical schools all over the world as a consequence of socio-economical and cultural changes.

Many instruments have been developed for diagnosing psychiatric disorders, but they are not fully adequate for evaluating a healthy population, such as medical students are expected to be. It is known that there is a higher incidence of anxiety, obsessive-compulsive disorder, depression, and suicide among students ${ }^{11-13}$ during the medical course, but this cannot be considered a pattern for the majority of them. On the other hand, it is also known that the incidence of psychosis and drug abuse is lower than in the general population $^{14}$, although when it does occur, it is worse and more often has tragic outcomes given their attributions as doctors. Therefore, it is important to use the appropriate personality tests, such as the 16 PF and the TAT applied in this study, in order to avoid a biased analysis.

Some results from the different instruments applied suggest that the group studied had a medical vocation, including: the early choice of medical career; the great interest in information about the profession before entering the medical school; their persistence in taking the vestibular exams many times even when discouraged to do so; their awareness of the difficulties and limitations for developing the career that might affect their personal life; their optimism re-

Table 2 - Number of students classified by gender and sten class for each bipolar personality factor and global factors, tested by the $\chi^{2}$ test or Fisher Exact test.

\begin{tabular}{|c|c|c|c|c|c|c|c|}
\hline \multirow[t]{2}{*}{ Factor } & \multicolumn{6}{|c|}{ Sten Class } & \multirow[t]{2}{*}{$P$} \\
\hline & female & male & female & male & female & male & \\
\hline A - Warmth & 4 & 6 & 23 & 22 & 3 & 2 & .825 \\
\hline C - Emotional Stability & 9 & 4 & 17 & 20 & 4 & 6 & .227 \\
\hline E - Dominance & 9 & 6 & 21 & 23 & 0 & 1 & .552 \\
\hline F - Liveliness & 3 & 6 & 22 & 17 & 5 & 7 & .418 \\
\hline G - Rule Consciousness & 4 & 7 & 23 & 20 & 3 & 3 & .600 \\
\hline H - Social Boldness & 7 & 4 & 18 & 20 & 5 & 6 & .602 \\
\hline I - Sensitivity & 1 & 11 & 27 & 19 & 2 & 0 & $.010 *$ \\
\hline L - Vigilance & 13 & 5 & 17 & 23 & 0 & 2 & $.029 *$ \\
\hline M - Abstractedness & 4 & 2 & 24 & 21 & 2 & 7 & .147 \\
\hline $\mathrm{N}$ - Privateness & 7 & 5 & 19 & 19 & 4 & 6 & .693 \\
\hline $\mathrm{O}$ - Apprehension & 2 & 4 & 18 & 15 & 10 & 11 & .653 \\
\hline Q1 - Openness to Change & 3 & 2 & 17 & 14 & 10 & 14 & .624 \\
\hline Q2 - Self Reliance & 8 & 6 & 21 & 20 & 1 & 4 & .361 \\
\hline Q3 - Perfectionism & 10 & 13 & 17 & 15 & 3 & 2 & .733 \\
\hline Q4 - Tension & 5 & 6 & 23 & 17 & 2 & 7 & .136 \\
\hline I - Extroversion & 4 & 3 & 21 & 22 & 5 & 5 & 1.000 \\
\hline II - Anxiety & 5 & 7 & 20 & 15 & 5 & 8 & .419 \\
\hline III - Tough-Mindedness & 5 & 4 & 24 & 23 & 1 & 3 & .794 \\
\hline IV - Independence & 8 & 4 & 20 & 24 & 2 & 2 & .407 \\
\hline V - Self-Control & 5 & 10 & 22 & 19 & 3 & 1 & .255 \\
\hline
\end{tabular}

* Statistically significant difference 


$$
\begin{array}{r}
10 \\
9 \\
8 \\
7 \\
6 \\
5 \\
4 \\
3 \\
2 \\
1 \\
0
\end{array}
$$

Sten

9

$\rightarrow$ Male

$\rightarrow$ - Female

8

7

6

5

4

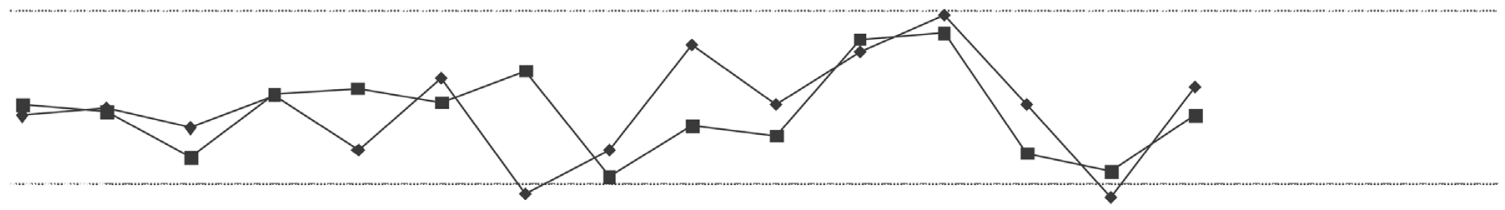

3

2

1

Bipolar personality

0

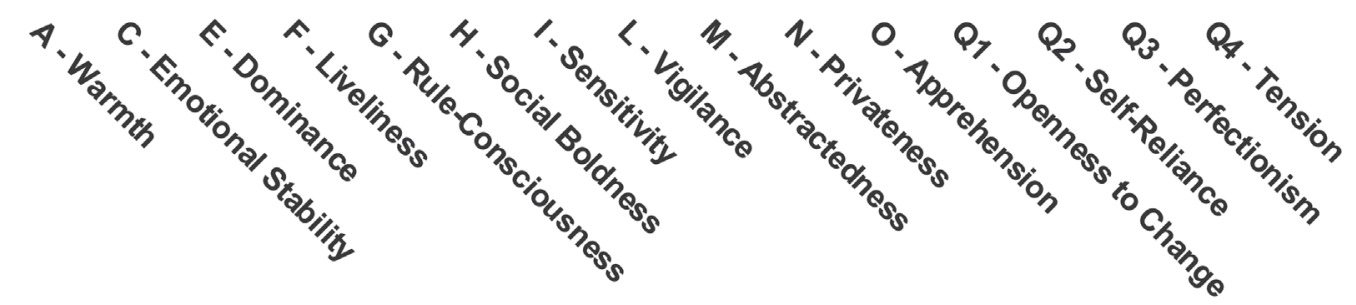

Figure 1 - Mean sten for bipolar personality factors for female and male groups.

garding their future professional prospects in the face of all the anticipated challenges; their strong humanistic values with respect to medicine; their openness to new experiences; the extent to which they identified with their choice of profession; the importance they placed on fulfillment of their careers; and their expression of a conscious and unconscious desire to help people and get the recognition of their usefulness, without being narcissistic. This latter point is the main aspect of medical vocation in our view, offering a possible answer to the question formulated in the beginning of this paper. All these qualities were seen in both genders.

The general $16 \mathrm{PF}$ profile for both genders was similar. These results demonstrate there are no scientific reasons that justify the prejudice to accept women in some medical specialties, as pointed out in the introduction. They also demonstrate that a medical vocation transcends gender and that the growing presence of women in the medical profession cannot be explained by the vocational aspects.

The study also revealed aspects that may be facilitators for entering the medical profession, such as family income, parents with higher education, having studied in a good high school and preparatory courses for the vestibular, and having doctors in the family, thus showing the relevance of many socio-economical factors in determining their career choice.

It is noteworthy to mention that although many previous investigations have dealt with career choice, they studied focal aspects: the moment of career choice ${ }^{15}$, the expec- tation for the medical career ${ }^{16}$, encouragement and discouragement for being a doctor ${ }^{17}$, desirable attributes of a physician $^{18}$, conscious motivations ${ }^{19}$, unconscious motivations ${ }^{3}$, or personality characteristics of the medical student. ${ }^{2}$ The greatest obstacle for assessing this area is the absence of a single instrument able to evaluate all factors and a specific one that directly measures vocation. One could infer mistakenly that it is not possible to assess medical vocation, while at the same time acknowledging medical vocation as an important element for professionals of different areas like medical psychology, vocational counseling, general and specialist medicine, psychological counseling, and medical education.

In order to offer a solution to this problem, this study proposes the utilization of a new model of medical vocation evaluation through the integration of 4 different instruments. Results obtained reinforce the importance of the psychological and sociological theories and the vocational theories cited previously. Future studies should be carried out in other medical and non-medical schools with the objective of testing this new approach to an old question.

\section{ACKNOWLEDGEMENTS}

We thank Mrs. Vera Belia Tancreda for helping in the organization of the project files, Mrs. Laura Faro for revising the text, and the students who dedicated part of their free time to be interviewed and to answer the tests. 
MILLAN LR e col. O que está subjacente à escolha do estudante pela profissão médica? CLINICS 60(2):143150, 2005.

OBJETIVO: Determinar as razões da escolha da profissão médica em um grupo de alunos do primeiro ano de medicina da Faculdade de Medicina da Universidade de São Paulo, investigando o perfil sócio-econômico e psicológico, e as diferenças com relação ao gênero dos alunos.

MÉTODO: Cento e sessenta e três alunos responderam a um questionário para avaliar seu perfil sócio-econômico. Destes, 30 mulheres e 30 homens submeteram-se a uma entrevista face a face sobre a escolha da profissão, ao Teste de Apercepção Temática (TAT) e ao teste 16 PF. Os resultados foram analisados qualitativamente e pelos testes de Mann-Whitney, $\chi^{2}$, Fisher's Exact e coeficiente $r_{p}$.

RESULTADOS: A maioria dos estudantes pertence à classe média, são católicos e possuem médicos na família. Estudantes de ambos os gêneros haviam escolhido precocemente a profissão e mostraram persistência para prestar o vestibular, mesmo quando desencorajados por terceiros. O estudo revelou consciência das dificuldades e limitações da carreira médica, bem como grande valorização dos aspectos humanísticos da medicina e espírito aberto a novas experiências. Verificou-se que a profissão ocupa um papel central em suas identidades, a relevância dada à satisfação profissional, o desejo consciente e inconsciente de ajudar os semelhantes e de serem reconhecidos por isso, sem a busca exclusiva de uma gratificação narcísica. As alunas apresentaram maior Brandura $(\mathrm{p}<0,001)$ e menor Imaginação $(\mathrm{p}=0,005)$ do que os alunos, que são mais práticos e criativos. As alunas apresentaram maior grau de maturidade, e os alunos maior competitividade e ambição.

CONCLUSÕES: Estudantes de ambos os gêneros apresentam um perfil semelhante quanto às motivações para a escolha da profissão e quanto ao perfil sócio-econômico. Pequenas diferenças foram encontradas quanto aos aspectos psicológicos.

UNITERMOS: Estudantes de medicina. Personalidade. Vocação. Gênero. Educação.

\section{REFERENCES}

1. Simmel E. The doctor game, illness and profession of medicine. IJP 1926;7:470-83.

2. Wender L. Psicoanálisis de la vocación. Rev Psicoanal 1965;22:6997.

3. Krakowsky AJ. Doctor-doctor relationship III: a study of feelings influencing the vocation and its tasks. Psychosomatics 1973;14:156-61.

4. Baird LL. The characteristics of medical students and their views of the first year. J Med Educ 1975;50:1092-9.

5. Schneider PB. Regards Discrets et Indiscrets sur lê Médicin. Paris: Masson, 1991.

6. Bohoslavsky R. Orientación Vocacional - la estrategia clínica. Buenos Aires: Editorial Nueva Visión, 1979.

7. Campos Silva LB. A Escolha da Profissão - Uma Abordagem Psicossocial. São Paulo: Unimarco Editora, 1966.

8. Lyons AS, Petrucelli RJ. Medicine: an illustrated history. New York: Abrams,Harry N Inc, 1987.

9. Murray HA. Uses of Thematic Apperception Test. Am J Psychiatry 1951;107(8):577-81.

10. Russell MT, Karol DL. 16 PF Fifth Edition Administrator's Manual. Champaign: Institute for Personality and Ability Testing, 1994.

11. Simon HJ. Mortality among medical students, 1947-1967. J Med Educ 1968;43:1175-82.
12. Lloyd C, Gartrell NK. Psychiatric Symptoms in Medical Students. Compr Psychiatry 1984;25:552-65.

13. Millan LR, Rossi E, De Marco OLN. O suicídio entre estudantes de medicina. Rev Hosp Clin Fac Med S Paulo 1990;45:145-9.

14. Baldwin DC Jr, Hugues PH, Conard SE, Storr, CC, Sheehan DV Substance use among senior medical students. JAMA $1991 ; 265: 2074-8$

15. Beedham T, Why do young doctors leave medicine. Brit J Hosp Med 1996;55(11):699-701.

16. Rosenthal MP, Turner TN, Diamond J, Rabinowitz HK. Income expectations of first year students at Jefferson Medical College as a predictor of family practice speciality choice. Acad Med 1992;67(5):328-31

17. Baird LL. The characteristics of medical students and their views of the first year. J Med Educ 1975;50:1092-9.

18. Sade RM, Stroud MR, Levine JH, Fleming GA. Criteria for selection of future physicians. Ann Surg 1985;201(2):225-30.

19. Barondess JA \& Glaser RJ. Attitudes toward the medical career: findings from the alpha-omega survey of college and university undergraduates. Acad Med 1993;68(5):323-8.

20. Green A, Peters TJ, Webster DJT. An assessment of academic performance and personality. Med Educ 1991;25:343-8. 